\title{
Filosofické aspekty Estetiky performativity Eriky Fischer-Lichte
}

\author{
Alice Koubová
}

\begin{abstract}
Abstrakt
$\checkmark$ tomto článku formuluji filosoficky orientovaný příspěvek k diskuzi nad stěžejním dílem německé teatroložky Eriky Fischer-Lichte Estetika performativity. Zaměřuji se na způsob, jakým se Fischer-Lichte odvolává na filosofické koncepce (zejména fenomenologii, poststrukturalismus a filosofii hry) při své interpretaci performančního umění a jeho estetiky. Ačkoli Fischer-Lichte tvrdí, že postupuje v tradici post-strukturalismu a odvolává se na Judith Butler, aby se jí podařilo dekonstruovat novověký dualismus, svými východisky a argumentačním postupem to popírá. Její blízkost k Judith Butler se tak stává pouze proklamativní. Klíčový úhybný manévr provede Fischer-Lichte ve chvíli, kdy se rozhodne operovat s performativitou na poli estetiky, kterou odlišuje od každodenní performance člověka ve světě. Obdobný úkrok Ize u Fischer-Lichte vystopovat i v rámci interpretace tělesnosti (Leib - Körper) a ve výkladu fenoménu hry. Své pojetí performančního umění nakonec opírá o avantgardní principy a její reflexe paradoxně potvrdí novověký dualismus v jeho převrácené podobě.
\end{abstract}

\section{Klíčová slova}

estetika performativity, performativ, prézentnost, Leib, Körper, událost, Butler, Fischer-Lichte

\begin{abstract}
In this article I am offering a philosophical perspective within the discussion of a seminal work by German theatre scholar Erika Fischer-Lichte, The Transformative Power of Performance. I am looking at how Fischer-Lichte applies philosophical concepts (such as phenomenology, post-structuralism and game philosophy), whilst interpreting performance art and its aesthetics. Although Fischer-Lichte claims that she relies on poststructural tradition, mainly on Judith Butler, in deconstructing modern dualism, her line of argumentation and key points contradict this. Thus, the parallels with Judith Butler are only declarative. The distance between the two scholars is especially notable when Fischer-Lichte uses the term "performativity" within the field of aesthetics, which she distinguishes from every-day human performance. In a similar manner, Fischer-Lichte interprets the term "corporeality" (Leib - Körper) and the phenomenon of play. Her understanding of the performing arts rests upon avantgarde principles, and her reflections, paradoxically, support modern dualism in its inverted form.
\end{abstract}

\section{Key words}

aesthetics of performativity, performative act, presentness, Leib, Körper, event, Butler, Fischer-Lichte 
Svou statí bych ráda přispěla $\mathrm{k}$ diskuzi nad stěžejním dílem německé teatroložky Eriky Fischer-Lichte Estetika performativity (FISCHER-LICHTE 2011). Vzhledem k mému vlastnímu odbornému zaměření se pokusím o něco, co by se dalo nazvat filosofickým čtením daného textu. Erika Ficher-Lichte totiž ve své teatrologické analýze performančního umění staví na relativně velkém množství odkazů na filosofické (zejména fenomenologické, poststrukturalistické a filosoficko-antropologické) koncepce a zároveň přes fenomén divadla a performance rozvijí obecná témata tělesnosti, performativity, hry a časovosti. Pro svůj výklad využívá rovněž důležitých pojmových distinkcí, které mají nejen teatrologickou, ale i obecně filosofickou relevanci. Je to dáno zajisté i samotnou povahou performančního umění, které je charakteristické svým zájmem o stopování, zkoumání a zkoušení (až pokoušení, řekl by Ivan Vyskočil) hranice mezi životem a uměním, historicitou a prézentností, opakováním a událostí, člověkem ve své pravdě a člověkem odcizeným sobě samému. Již volbou těchto distinkcí se však činí filosofická rozhodnutí. Tato filosofická rozhodnutí se pak na základě jejich konkrétního užívání, zdưrazňování či popírání podílejí na vtěleném, performativním filosofování lidské existence ve světě. Filosofie se zde tedy neuplatňuje pouze jako předpoklad, nástroj a východisko, ale také jako (postupně prosazená) interpretace člověka ve světě.

Na začátku je vhodné zmínit, že první verze tohoto článku je součástí mé nedávno publikované monografie Myslet $z$ druhého mista. K otázce performativni filosofie (KOUBOVÁ 2019). V dané knize a v kontextu, který mě v ní zajímá, se vůči Estetice performativity vyjadřuji kriticky. Díky několika důležitým podnětům ze strany Martina Pšeničky a Elišky Poláčkové mám tendenci některá svá př́lišs kritická tvrzení revidovat v rámci tohoto textu. Stále bych však ráda tvrdila, že to, co svým výkladem performančního umění Erika Fischer-Lichte zamýšlí dekonstruovat (subjekt-objektový rozštěp, hierarchie moci), svými popisy naopak subtilně upevňuje a nedaří se jí tedy zachytit performanční umění v jeho komplexní povaze. Její původní motivace je přitom velmi srozumitelná a obhajitelná, nicméně mou snahou bude ukázat, že si pro svưj záměr nezvolila vhodný postup.

\section{Východiska}

Jak je všeobecně známo, počátky a genealogie performančního umění jsou poměrně komplexní. Marvin Carlson ve své přehledové monografii Performance. A Critical Introduction (CARLSON 2018) uvádí a analyzuje v zásadě dva kořeny performančního umění. Tím prvním je hnutí avantgardy a modernismu ve smyslu hnutí, které staví na nenarativní, neinscenační, nemimetické formě divadla bezprostřednosti, se zásadním důrazem na pojem "př́tomnosti“ a potřebou dobrat se uměleckými prostředky autentického jádra aktéra-lidské bytosti (GREENBERG 1962; FRIED 1968). Rétorika avantgardy apeluje na očištění jednání od nánosů sociálních masek, na hledání původního komunitního a tělesného propojení mezi aktéry, na osvobození umění od interpretačního násilí, projektů a hodnocení.

Druhým zdrojem performančního umění je dle Carlsona postmoderní a poststrukturalistické myšlení. Tento proud zdůrazňuje, že lidské self je sociálním konstruktem, 
součástí strukturních vazeb moci, zvyků a normativity, které nemůže transparentně uchopovat a mít je pod kontrolou. Z toho důvodu si je člověk přístupný vždy jen nutně necele, fragmentárně, nedokončeně. Žije jako součást světa, v jehož rámci se jako součást světa uchopuje. Pohybem uchopování sebe sama člověk navíc svůj vlastní počátek přesouvá. Žije tedy nikoli jako rozpadlé Self, ale jako sebezdvojení. Z toho vyplývá i nemožnost zkušenosti ve smyslu př́tomněni (CARLSON 2018: 91-105). Stejnou podvojnost kořenů diskutuje také Alice Lagaay v knize Metaphysics of Performance (LAGAAY 2001: 37) a zdůrazňuje, že tyto dva zdroje performančního umění mají zároveň jednoho společného jmenovatele: je jím kritika tradičního dualismu těla a mysli, hierarchické vazby mezi původní substancí mysli a odvozenou substancí těla, statickou nerozlehlostí a věčností mysli oproti proměnlivé, rozlehlé a pomíjivé tělesnosti. Oba kritické př́ístupy staví svou kritiku na zdůrazňování existence a důležitosti zkušenosti, která není bezprostředně vědomá, přítomná v naší mysli, která není diskurzivně uchopitelná a která se přesto podílí na konstituci významů a je součástí zážitku smysluplnosti. Způsob, jakým se obě kritiky dualismu snaží tuto nediskurzivní zkušenost lokalizovat, zachytit či myšlením doprovázet, je však zásadně odlišný. Avantgarda věří, že nediskurzivní zkušenost je možno chápat jako hlubší původnost a zdroj určité silnější autenticity přítomnosti, často spojenou s fyzickou daností, senzuálním prožitkem, materialitou tělesné existence. Postmoderna naopak chápe nediskurzivní zkušenost jako zdroj narušování a znemožňování dosáhnout původu v rámci působení sil moci, které jsou součástí anonymně, či netransparentně probíhající konstituce lidského já ve světě.

Z takového popisu se zdá, že v pozadí performančního umění již od počátku stojí dvě pojetí reality, které se shodnou na tom, co odmítají, ale nesdílejí spolu důvod tohoto odmítnutí a tím pádem ani způsob, jak odmítnutý postoj překonat.

Tato filosofická ambivalence, jak se budu snažit ukázat, doprovází i celou Estetiku performativity Eriky Fischer-Lichte. Ačkoliv se Fischer-Lichte snaží systematicky, podrobně a argumentačně propracovaně obhájit funkci nediskurzivní zkušenosti v rámci divadelní tvorby, což je velmi důležitý a záslužný záměr, osciluje její úsilí mezi dvěma postoji sociopolitickým hlediskem poststrukturalismu a avantgardní ideou pravdivé tělesnosti bez sociálních nánosů. Když hledá způsoby, jak vysvětlit neredukovatelnost divadelního představení na jeho výklad, jak představit významnost neverbálních, emočních, tělových a emergentních forem působení performance, nedaří se jí vyřešit ambivalenci těchto dvou postojů. Své poněkud zamlčené dilema řeší př́íklonem $\mathrm{k}$ avantgardě a dezinterpretací ostatních filosofických zdrojů, na které se však zároveň explicitně odvolává. Pokusím se ukázat, že klíčový úhybný manévr se stane ve chvíli, kdy se Fischer-Lichte rozhodne operovat s performativitou na poli estetiky, a nikoli na poli sebeporozumění člověka ve světě. Tím paradoxně potvrdí novověký dualismus $v$ jeho převrácené podobě (tělo se ukáže jako původní substance a mysl jako jeho odvození) a mocenský boj mysli a těla tím spíše upevní. 


\section{Performativ divadelní a skutečný}

Genezi konceptu performativity začíná Fischer-Lichte vykládat přes Austinovu teorii řečových aktů. Austin zavádí rozlišení mezi koncepty konstativu a performativu. Konstativ je takový výpovědní akt, který prostě oznamuje, podává zprávu o stavu nějaké věci, je schopen „konstatovat určitou skutečnost“ (AUSTIN 2000: 19). Konstativ odkazuje ke skutečnosti mimo sebe a něco o ní konstatuje. Performativ naopak svým vyslovením skutečnost, kterou označuje, vykonává; to, čím je, také dělá, je tedy v tomto smyslu nereferenční. Austin však následně nahlíží, že dané dělení je nepřesné, protože v podstatě každým podáním zprávy o něčem je skutečnost zároveň vždy nějak performována, formována, interpretována. Zruší tedy své vlastní rozlišení na konstativ a performativ a začne tvrdit, že všechny mluvní akty jsou performativní. Nabídne zároveň dělení jiné. Začne klasifikovat performativy podle toho, zda mají, či nemají reálný vliv na skutečnost. Jinými slovy rozlišuje performativy, které „skutečně“ dělají to, co říkají, a performativy, které pouze dělají, „jako by“ dělaly, co říkají, ale „ve skutečnosti“ to nedělají. Některé performativy dělají „tvrdou realitu“ a jiné jsou „jen hrou“ na dělání, ale na realitu dopad nemají. Austin tím separuje pravé, čisté performativy, kde intence mluvčího je v souladu s tím, co pronáší, od performativů-her. Odlišuje performativy, které se skutečnosti týkají, a ty, které se jí nechtějí týkat. Performativy, které nemají s vlivem na realitu nic společného, označuje Austin jako tzv. parazitní performativy a navrhuje je vyloučit ze sféry zdařilých řečových aktů. Mezi tyto performativy patř́i citováni druhých a umělecká řě, speciálně reč hercova na divadelni scéně. V parazitních formách performativ údajně nenaplňuje svou funkci, kterou je, dle Austina, úspěšnost, zdařilost ve smyslu reálné akce a vyplnění upřímného záměru v mysli mluvčího. Divadelní promluva je tak odsunuta z roviny seriózních promluv do roviny pouhé hry na seriózní promluvy. Promluva v rámci divadelní performance je nepravá, nebot herec ve skutečnosti nemá zájem, aby to, co prohlašuje, bylo uskutečněno.

\section{Trii přístupy k Austinovu dělení}

Toto dělení tedy klasifikuje umělecký projev jako nepravý, parazitní a odvozený od pravé reality. Na takové pro umění nelichotivé vyústění původně odvážné myšlenky je možné reagovat třemi možnými způsoby.

Zaprvé je možné na Austinovo dělení performativů přistoupit, ale začít provozovat umění jako realitu. Když se má performerka říznout, tak se prostě řízne nožem do těla, když se má nechat performer střelit, nechá se střelit skutečným nábojem do paže, když má performer koexistovat s kojotem, vstoupí do uzavřeného prostoru s živým kojotem a hledá způsoby jejich společného soužití. Je tedy možné rozvíjet umělecké performance, které své performativy myslí naprosto vážně a které prostě dělají to, co říkají. V tomto případě je snahou provozovat umění jako předvádění a zároveň provádění skutečnosti (či jako předvádění provádění skutečnosti). Praktické experimentace 
s těmito formami uměleckého výrazu a s hranicemi mezi „jakoby“ a „skutečně“ charakterizují právě mimo jiné performanční umění.

Druhou možností je na Austinovo dělení přistoupit, ale hledat pro umělecký performativ jiné kritérium skutečnosti, pravosti a svébytnosti. Tento přístup vychází z připuštění, že umění není totéž co vážná realita, odmítá ho však chápat jako na vážné realitě parazitující. Místo toho představuje umění jako skutečnost jiného druhu. K této možnosti se dostaneme ještě později v souvislosti s Erikou Ficher-Lichte.

Třetí možnost nabízí poststrukturalismus Jacquese Derridy a následně Judith Butler. Ti na Austinovu separaci nepřistupují.

\section{Poststrukturalistické třetí řešení}

V článku „Signatura, událost, kontext“ z roku 1972 Derrida ukazuje klíčovou funkci divadelní řeči, když ř́ká: „Není totiž nakonec to, co Austin vylučuje jako anomálii, výjimku, ,nevážnost', není citace (na jevišti, v básni anebo při samomluvě) pouze jistou modifikací obecné citovatelnosti - obecné iterability -, bez níž by nebylo ani ,zdárného“ performativu? A tedy - což je sice paradoxní, nicméně nevyhnutelný důsledek - není to tak, že zdařilá performativní výpověd' je nutně ,nečistá', abychom použili slova, jehož bude Austin používat později, když připustí, že vlastně ,čistý‘ performativ neexistuje?“ (DERRIDA 1993: 298-299).

Pokud se tedy podíváme na hercovu řeč a vidíme její citační, iterativní povahu, můžeme díky ní odhalit důležitý poznatek o performativu obecně: jakýkoliv performativ odkazuje sám na sebe ve smyslu citace všech svých předešlých výskytů. Performativ tedy neodkazuje sám na sebe tady a ted', ale sám na sebe mnohokrát dosud a ve všech dosavadních situacích. Performativ je iterací svých vlastních proslovení. S každým novým vyslovením se navíc význam performativu, jeho kontext či dopad posouvá. Přestože performativ rozpoznáváme v jeho opakování, víme také, že každé opakování zahrnuje nepřesnosti, posun významu.

Z Derridova výkladu vyplývá, že ačkoliv není divadelní představení a divadelní řeč totéž co skutečnost a každodenní řeč, není nezbytné se na tento rozdíl filosoficky zaměřovat. Tohoto rozdílu si všichni všímáme již zvykově, jsme navyklí tyto dvě situace rozlišovat podle toho, že jedna je skutečná, kdežto druhá skutečná takzvaně není, nebở je „jenom jakoby“. Necháme-li však toto rozlišení pro jeho nezajímavost stranou, můžeme zahlédnout naprosto jiný fenomén. To, co touto cestou objevíme, je fenomén citovanosti performativů a jejich vnitřních posunů při každém novém vyslovení. Díky tomu, že divadelní performativ vezmeme vážně, pochopíme podstatu performativu jako takového. Jen díky prožitku divadelní řeči, která měla být parazitní a jejiž status vůči běžné řeči na chvíli přestaneme řešit, se zjevuje vlastní povaha řeči, skutečnost performativu.

Judith Butler tuto Derridovu interpretaci přejímá a dále rozvíjí. V knize Excitable Speech (BUTLER 1997) rozšiřuje řečové performativity na performativitu kulturních projevů, v článku „When Gesture Becomes Event“ (BUTLER 2017) rozšiřuje pojem performativu na performanci, tedy tělesné společenské jednání. Tvrdí, že řečové akty jsou vždy 
nutně ztělesněné a že jednotkou řečového aktu ve společenském jednání je tedy performance (i Austin sám hovoří o „performanci lokučního aktu“, AUSTIN 2000: 101).

\section{Navázání Fischer-Lichte na poststrukturalismus}

Ve své Estetice performativity se Fischer-Lichte na začátku explicitně odkazuje na právě uvedené tvrzení J. Butler a hlásí se k poststrukturalismu. Souhlasí s tím, že pojem performativ nemusí být užíván výhradně ve spojení s mluvními akty, ale že vzhledem k mimojazykovým podmínkám uskutečnění performativu a k jeho zasazení do institucionálně-společenského rámce je třeba vnímat performativ jako součást tělesného jednání. Performativ je ztělesněná akce, ztělesněné uskutečnění toho, co je vyjadřováno. $\mathrm{V}$ tomto smyslu je pak možné od pojmu performativ přejít k termínu performance jako ztělesněné akce.

Fischer-Lichte dále podporuje tvrzení J. Butler, že performativ je dramatický a nereferenční. Tyto dvě charakteristiky, které Fischer-Lichte zdůrazňuje jako potvrzení svého pojítka k poststrukturalistické teorii performativity J. Butler, jsou poměrně klíčové.

Pro Judith Butler je dramatičnost performativu charakterizována takto: „Za dramatický označuji fakt, [...] že tělo není pouhá látka, ale neustále probíhající zhmotňování možností. V jistém smyslu člověk není svým tělem, člověk své tělo vytváří“ (BUTLER 1990: 273).

V jejím podání tedy není tělo nikdy něčím přítomným, co by splývalo s tím, čím je daný člověk a jak se daný člověk myslí. Tělo se neustále vytváří, je v předstihu před tím, jak je myšleno, a v závěsu za tím, jak je myšleno. Nelze ho redukovat na materialitu oddělenou od uskutečňování záměrů, rámování normami, ale ani s nimi nesplývá. Dramatičnost performativu spočívá v tom, že v něm není možno oddělit prosté tělo od čiré myšlenky a že neexistuje ani nic takového jako vtělená mysl tady a ted'. Myslet tělo znamená jednak uchopit ho nutně normativně a jednak ho sledovat v jeho síle jako schopnost pohnout myšlením a překročit jeho hranice. Vtělená mysl je místo dramatického napětí, nikoli místo prolnutí a spojení.

Pokud jde o nereferenčnost performativu, znamená to, že performativ neodkazuje jako formální znak k nějaké skutečnosti, kterou sám není, ale že odkazuje pouze sám na sebe. J. Butler ukazuje, že toto „samo na sebe“ znamená, jak jsme viděli výše, odkaz na svá vlastní minulá ztělesnění. Performativ má moc vykonat to, co označuje, díky odkazu na řetězec svých vlastních dosavadních výskytů. Jako takový nikdy nepůsobí instantně, tady a ted'. Performativ existuje tak, že je vlivný a vlivný až jako druhý, třetí, čtvrtý výskyt sebe sama, nikoli jako singulární náhlá událost prorážející čas i prostor. Povahu události získává naopak performativ úplně jinou cestou. Butler v již zmíněném článku „When Gesture Becomes Event“ ukazuje, že událostní charakter performativu vzniká díky jeho dekontextualizaci skrze (divadelní) gesto, skrze vyjmutí z jeho vlastní historie a skrze jeho předvedení ,jako kdyby to bylo poprvé“. Toto ,jako kdyby poprvé“ je jediným způsobem, jakým performativ může vůbec disponovat nějakým „poprvé“. Jeho původnost má povahu překvapující sebedistance v řetězci vlastních 
opakování. V této sebedistanci, v sebezdvojení spočívá událostní povaha performance, říká Butler.

Fischer-Lichte na začátku knihy tvrdí, že si myslí totéž, co J. Butler, ale v celé své knize nakonec realizuje tvrzení opačná: bude vysvětlovat, že performanční umění směřuje $\mathrm{k}$ užívání performativu $\mathrm{v}$ jeho čisté tělesné prézentnosti, $\mathrm{k}$ emergentnímu výrazu očištěnému od nánosů tradice, verbalizace, myšlenek, záměrů a norem. Performanční umění vytváří podle ní takové podmínky, v nichž může vyvstat něco úplně poprvé, bez minulosti a budoucnosti, něco, co se stane jedině tady a ted'.

\section{Estetický argument}

Této přesmyčky dosahuje Fischer-Lichte překvapivě argumentem estetickým. Navrhuje totiž zrušit důraz J. Butler na „každodenní performativ“ a nalézt pro oblast estetiky ,jinou definici, než termínu ,performativní přisuzuje J. Butler, a to především proto, že se zde jedná o estetická, tudíž ,posunutá opětovná provádění. J. Butler se odvolává ke každodennímu jednání a téměř nikdy k estetickým dějům" (FISCHER-LICHTE 2011: 37). Z toho je patrné, že Fischer-Lichte souhlasí na rozdíl od Butler s Austinovým dělením na štastný (pravý) a nepravý performativ a snaží se o to, co jsem uvedla jako druhou možnost reagování na Austinovu distinkci: ta spočívala ve snaze vymyslet pro oblast umění jiná kritéria platnosti tak, aby nebyla umělecká řeč pouze parazitní, ale aby se ukázala stejně významná jako „vážná“ skutečnost. I když vyhlášením války na divadelní scéně nespustí herec válku v př́slušném demografickém regionu, je možné zjistit, v jakém smyslu je jeho performativ účinný jinak - esteticky. Místo devalvace chce Fischer-Lichte divadelní řeči přiřknout výjimečnou, estetickou hodnotu a jiná kritéria úspěšnosti. Tím, jak je možná již zřejmé, Fischer-Lichte ztrácí onu jemnou, subtilní, a přesto rozhodující vazbu mezi skutečností a divadlem, kterou poststrukturalismus využil proto, aby předvedl divadelní performativ jako naprosto klíčovou kategorii pro porozumění lidské situaci jako takové.

\section{Konstativ a performativ}

Fischer-Lichte nicméně nepřistupuje pouze na kategorizaci dvojího druhu performativů, ale dokonce se přiklání $\mathrm{k}$ dualismu mnohem nápadnějšímu, který u sebe korigoval i samotný Austin: dualitu konstativu a performativu. Jak se to přesně stane? Opět začíná tím, že Austinovo sloučení konstativu s performativem podporuje ve prospěch destrukce „binárních opozic jako subjekt-objekt nebo označující-označované“ (FISCHER-LICHTE 2011: 31), avšak o několik stran později navrhuje striktní binární opozici mezi divadlem ve smyslu inscenace dramatického textu a představením, performancí. Přeložíme-li toto dělení do roviny Austinova výkladu, jde o rozlišení mezi „pouhou reprezentací“ a performančním „uskutečněním“ (FISCHER-LICHTE 2011: 55), jinými slovy mezi konstatováním dramatického textu a autoreferenční performancí (FISCHER-LICHTE 2011: 31). 
Toto dělení následně podporuje s odkazem na Maxe Herrmanna, který dle ní „zaměřil svou pozornost výhradně na představení“ (FISCHER-LICHTE 2011: 39). Herrmann tvrdí, že smysl divadla je určen především představením, nikoli dramatickým textem. Když sledujeme výklad dál, Hermann stopuje původ divadla ve hře: „Původním smyslem divadla [...] bylo divadlo jako společenská hra - hra všech pro všechny. Hra, na níž se podílí všichni - herci i diváci. Publikum je chápáno jako spoluhráćc (HERRMANN 1981: 19). Fischer-Lichte chce touto cestou tvrdit, že performance je hra a jakožto hra stojí mimo konstatování normativity vztahů, historicitu a časovost běžného života.

Z Herrmanna Erika Fischer-Lichte vyvozuje, že mezi textem, něčím, co je opakovatelné, a představením ve smyslu hry (charakteristické jedině svou neopakovatelností) není vůbec žádný vztah a že je nutné zajistit, aby „základní rozdíly [...] zabraňovaly jejich vzájemnému propojení“ (FISCHER-LICHTE 2011: 39). Hovoří o nutnosti „převrácení hierarchických pozic“, o „nadvládě představení nad textem“ (FISCHER-LICHTE 2011: 41), o přednosti rituálu nad tradovaným mýtem. Když mluví o sekundaritě mýtu (FISCHER-LICHTE 2011: 40), myslí tuto sekundaritu jako hierarchicky nižší, odvozenou z dění, bez vlastní hodnoty.

\section{Filosofie hry}

To, co však mnozí filosofové hry dokládají v podrobných úvahách o ontologii hry, je opět výrazně jiná vazba hry k svému vněǰšku, než jak to líčí Fischer-Lichte. Ačkoliv je totiž hra autopoietická, autotelická aktivita, tedy aktivita, která má cíl v sobě samé a která skutečně generuje vlastní význam (Huizinga tomu ř́ká vtip hry, Spariousu mluví o smysluplnosti vlastní hře samé), neznamená to, že tento fakt zabraňuje vzájemnému propojení hry a vněǰ̌ku hry. Právě naopak. Hra je hrou právě proto, že má nějaký smysluplný vnějšek, něco, co hrou není. Hra má horizont, je ohraničená v čase, prostoru a skrze pravidla - v rámci těchto kategorií generuje autopoietický význam. $\mathrm{V}$ tomto smyslu však také, v potřebě vlastní hranice, a tedy i neprázdného, netriviálního vnějšku, je hra závislá na tom, čím není (na svém vnějšku). Hra se jako hra etabluje tak, že si s vnějškem pohrává, nabourává ho, zesiluje, paroduje, popírá, ignoruje a přerušuje. Hra „má svou platnost vně norem rozumu, povinnosti a pravdy“, říká Huizinga (1971: 145) a na jiném místě doplňuje: „Hra stojí mimo proces bezprostředního uspokojování nezbytných potřeb a žádostí, dokonce tento proces přerušuje“ (HUIZINGA 1971: 16). Hra není ani fyziologicky a instinktivně bezprostřední (není pudová), ani racionální a rozumná (není projektem). Je však vůči svému vnějšku vztažena, a to tak, že ho přerušuje, narušuje ho, vytváŕí k němu odstup, distanci. Díky této specifické lhostejnosti $\mathrm{k}$ vnějšku, afirmativnímu odstupu $\mathrm{k}$ vnějšku, dává hra svému vnějšku možnost si rozumět, re-flektovat se, uvědomit si sebe sama a ustavit se jako vnějšek hry. V zásadě dělá hra s životem totéž, co herecký performativ s obecným performativem. Díky hře se skutečnost stává zjevnou. Hra jako sekundárni se právě touto vazbou k vněǰ̌ku stává primární kategorií života (HUIZINGA 1971: 11-12), odkazuje k minulosti, nevylučuje užívání vyprávění, mýtů, textů, historických skutečností, modelů, vzorů, imitací, citací. 
Její výsostnou funkcí je však tyto referenty užívat ke svému vlastnímu užitku, do jisté míry svévolně, podle vlastních pravidel, ne nutně podle pravidel pudové fyziologie, společenské normativity, racionálního užitku nebo habitu. Hra je gesto, dekontextualizace historického materiálu, normy i života. Hra opakuje skutečnost, ale opakuje ji v pobláznění, jinak a v přebytku. Přebytkem nemíním kontrolu nad vnějškem, ani odvozenost od vnějšku. Míním tím ale závislost, topologickou vazbu. A právě díky ní se stává hra klíčovou pro možnost pochopit to, co opakuje, změnit to, co opakuje, dát prostor novému, které se ukáže jen z opakování.

\section{Dualismus}

Na místo využití těchto charakteristik hry zavádí Fischer-Lichte ve jménu emancipace divadla dualismus, který si nezadá s dualismy, které plánovala „rozrušit“, „destabilizovat“, „dostat do pohybu“ (FISCHER-LICHTE 2011: 31). Performanční umění očištuje od inscenace a nazývá ho nezávislou hrou. Hru chápe jako afirmativní sebedanost oddělenou od vážné reality. Jako hlavní charakteristiku performančního umění pak uvádí prézentnost a čistou tělesnost dění uvnitř hry: „hercovo tělo - především nahé tělo [je] vnímáno jako místo a esence prézentnosti“ (FISCHER-LICHTE 2011: 212). Toto čisté tělo je zbaveno referencí k čemukoliv mimo sebe, je materialitou, nahotou na scéně, která je tím, čím je. Zdroj významu, „umělecký charakter - estetičnost - nenáleží představení na základě vzniklého díla, ale probíhající události“, která je zase dána na základě „spoluprožívání skutečných těl ve skutečném prostoru“ a díky „jedinečné materiálnosti představení, které formují herci svými těly“ (FISCHER-LICHTE 2011: 45). Díky ztrátě zájmu o „fiktivní postavu ve fikčním světě stvořenou hraním“ (FISCHER-LICHTE 2011: 45), díky zrušení možnosti distance - „divák není svědkem daných procesů - během představení se jich přímo účastní a zakouší je na vlastní kůži“ (FISCHER-LICHTE 2011: 55), se zde dotýkáme možnosti, kterou jsem uváděla jako první možnou reakci na Austinovo dělení performativů - předvádění provádění. Performance je setkáním lidí, kteří dělají skutečné věci, ovšem dělají je ve vymezeném prostoru a odděleně od skutečnosti - v jistém paradoxním smyslu tak dospívají k ideji konceptu.

Tím se však Fischer-Lichte dostává do jakéhosi argumentačního zacyklení. Nejprve se vymezila vůči J. Butler argumentem, že její pojetí performance je pojetí estetické, které se nezabývá každodenností. Vytvořila rámec pro estetické performance, ve kterém je však hlavním tématem prožívání skutečných těl ve skutečném prostoru. Jediným rozdílem oproti každodenním performancím je tedy to, že estetické performance jsou vystavené každodenní performance (vystavené očím a tělům účastníků jako koncept).

Fischer-Lichte tak dává důraz na skutečnou živost prožívání v rámci performančního umění, ovšem paralelně popírá fakt, že by toto prožívání mělo svědky. Popírá tedy, že i v př́padě těch nejvíce imerzivních performančních formátů jsou si účastníci vědomi, že se jedná o rámovanou aktivitu, vystavenou jejich vlastnímu pozorování (ale zároveň to $\mathrm{v}$ zásadě tvrdí). Popírá, že v performančním umění účastníci přicházejí na událost $\mathrm{s}$ vědomím, že přišli na událost. Že tuší, že se v této časově a prostorově ohraničené 
performanci nebudou uplatňovat standardní pravidla divadelního představení, ale pravidla jiná. Někdy je obsahem dané performance vyjednávat tato pravidla, nebo je odhalovat. Účastníci jednají v performanci a zároveň jsou velmi zbystřenými svědky vlastního jednání a jednání druhých - toto (konceptuální) zdvojení však Fischer-Lichte nezdůrazňuje. Místo toho tvrdí, že jde o bezprostřední dělání běžné skutečnosti a že tato bezprostřednost má zároveň estetickou kvalitu, která není tímtéž jako kvalita běžné skutečnosti. Má tendenci medialitu performance zrušit, prohlásit performanci za čistou událost, za hru oddělenou od svého vnějšku. Pro takovou performanci je však třeba vymyslet „speciálni““ energii emanující v její vlastní bezprostř̌ednosti, autenticitě a živosti (liveliness), nikoli vyplývající ze zážitku dekontextualizace (FISCHER-LICHTE 2011: 84). Energie, kterou zde Fischer-Lichte zavádí jako zdrojovou, je energie afektivní: „Tělesnost má zde afektivní sílu, díky níž mohou vyvstávat nové významy“ (FISCHER-LICHTE 2011: 116). Tělo, se kterým Fischer-Lichte operuje, je odděleno od myšlenkových schémat. Tělo performance má svou vlastní duchovnost: „samo tělo [je] něco duchovního" (FISCHER-LICHTE 2011: 117). V herecké metodě to pak znamená, že „[h]erec nepropůjčuje své tělo mysli, a nevtěluje tedy cosi duchovního (konkrétně předurčené myšlenky), nechává svou ,mysl 'vystoupit skrze tělo, přičemž ,hybatelem ' je tu tělo“ (FISCHER-LICHTE 2011: 117). Touto cestou představuje Fischer-Lichte tělo bez sebeodstupu, kontextu, ambivalence a vývoje a nabízí tělo jako „okamžitý [...] smyslový prožitek a stravující afekt“" (FISCHER-LICHTE 2011: 136), kterému nelze odolat, který podmaňuje, ovládá prostor a strhává pozornost. Vrcholem tohoto vypjatého výkladu je tvrzení, že v nehistorické prézentnosti se uvolňuje proudící energie, transformační a životní síla (FISCHER-LICHTE 2011: 143), jež je jako jediná schopna „naplnit př́íslib štěstí civilizačního procesu“ (FISCHER-LICHTE 2011: 143).

\section{Fenomenologie tělesnosti}

Výklad, který se týká tělesnosti, opírá Fischer-Lichte o implicitní reference k fenomenologii tělesnosti. Zmiňuje distinkci Leib - Körper, tedy distinkci mezi prožívaným tělem-Leib oproti tělu-rozprostraněnému objektu ve smyslu Körper. Interpretuje je však jinak - jako vlastní, osobní tělesnost herce-lidské bytosti („Leib“) versus „čisté“ odosobněné sémiotické tělo, které k vlastní hercově tělesnosti nemá vztah („Körper“) (FISCHER-LICHTE 2011: 112). Prožívané, žité tělo, Leib, ovšem ve fenomenologii neznamená osobní tělesnost, která se separuje od norem, zvyků a vizí a existuje v prézentnosti jako energetická moc. Leib je tělo žité v rámci bytí-ve-světě. Bytí-ve-světě je přitom vtěleným uskutečňováním lidského rozuměni světu a jeho možnostem. Tělesnost-Leib je situační žitá tělesnost našeho sociálního, komunikačního života i života v sebevztahu a zahrnuje v sobě jak naši „vrženost“ do světa, přijetí druhými a vepsanost do norem společenství, naši tělesnost práce a užívání těla, tak i naši možnost projektů do budoucna, plánů a možností strukturovaných naší minulostí a sebeporozuměním. Fenomenologie tělesnosti nemluví o čisté osobní autopoietické materialitě. Čistá materialita naopak charakterizuje tělo jako rozprostraněný materiální objekt, 
Körper, karteziánskou předmětnost. Aby mohlo být tělo-materie původním „hybatelem“, přiděluje mu Fischer-Lichte neurčitou moc, následně i duchovnost a nakonec i mysl, která však nesmí zahrnovat myšlení generované skrze naše bytí s druhými, bytí v normách a společenství, skrze reflexi, intenci, plánování, rozvažování, sebekritičnost, motivaci apod. To, co Fischer-Lichte popisuje, je tedy „převrácení hierarchických pozic" v karteziánském dualismu.

Toto karteziánství naruby rozkrývají i další autoři, např́ílad Philip Auslander ve své knize From Acting to Performance (AUSLANDER 2006). Jak Auslander ukazuje, př́istupy, které mají tendenci tělesnost očistit od verbalizace znaku, přehlížejí, že „čistě fyzický výraz těla a tělem je nemožný pro takové tělo, které je samo diferencováno a není př́tomno sobě samému [...]. Tělo nemůže vyjadřovat mysl, aniž by bylo definováno jejím vlastním systémem diferencí. Čiré sebe-vystavení není na fyzické rovině o nic více možné než na verbální rovině, nebot zprostředkovává diference“ (AUSLANDER 2006: 35-36).

Z tohoto důvodu ,[k]lást tělo jako absolutní, původní přítomnost mimo značení není ani přesné, ani teoreticky obhajitelné. Problém performujícího těla spočívá v napětí mezi faktem, že tělo vždy slouží jako označující a zároveň tuto funkci překračuje, aniž by ji opustilo zcela“ (AUSLANDER 2006: 35-36). Odvolává se přitom na Ericksonovo tvrzení: ,je-li naším záměrem prezentovat tělo jako maso [...] zůstane tělo stejně znakem [...]. Když chceme předvést performerovo tělo primárně jako znak [...], tak se do toho tělesnost vždy vloží“ (ERICKSON 1995: 66n).

\section{Problematické důsledky}

Výklad Fischer-Lichte v sobě nese mnoho z klasického výkladu dionýského aspektu umění a s tím souvisí i specifické problémy. Sama autorka některé z nich popisuje, když analyzuje momenty $\mathrm{v}$ rámci některých performancí, v nichž se prožitky extáze a emerze kombinují s nekontrolovatelným narušováním hranic, manipulací či závislostí, které nakonec mohou být i bolestné. V popisu Schechnerova představení Dionysus in '69 Fischer-Lichte např́íklad připouští, že navzdory Schechnerovu tvrzení o rovnocennosti partnerských subjektů a demokratizaci představení docházelo během představení „k utiskování performerů a někdy i násilí ze strany ,uvolněných“ divákư“ (FISCHER-LICHTE 2011: 57). Některé performerky se opakovaně cítily sexuálně zneužívány a prostituovány, přičemž tento pocit nabyl skutečného rozměru.

Fischer-Lichte však uvádí ještě další př́ípady performancí, ve kterých nedospívají účastníci do situace štěstí civilizačního procesu. Např́klad známou performanci Coco Fusco a Guillerma Gómez-Peña s názvem Dva neobjeveni indiáni navštěvuji... charakterizoval dle autorů samotné performance i dle Fischer-Lichte „mocenský boj“ a „soupeření o definiční a interpretační nadvládu“ (FISCHER-LICHTE 2011: 64) mezi performery a diváky. Pohyb v oblasti, která nenabízí rozlišení reality a fikce, vede ke znejistěním, která kulminují v mocenském boji o ovládnutí pole vlastní interpretací. V rámci performance Chance 2000 - Volebni cirkus '98 Christopha Schlingensiefa docházelo ke 
zrušení dělení na performery a diváky a nastolena byla hra všech se všemi - až na jednu výjimku. Tou byl režisér celé performance Christoph Schlingensief sám: „Až na malé výjimky se režisér zúčastnil všech představení a řídil je - jeho dominance tak byla $\mathrm{v}$ protikladu $\mathrm{k}$ vyhlášeným pravidlům představení $\mathrm{i} \mathrm{k}$ jeho průběhu, kdy se zdálo jakékoli vedení téměř nemožné“ (FISCHER-LICHTE 2011: 65). Otázkou je, zda se jednalo v tomto případě o svobodnou hru všech se všemi nebo o (manipulativní) hru režiséra se všemi ostatními, kteří si jeho moci nebyli od začátku hraní vědomi. Objevují se tak radikální politicko-etické otázky: „Kdo má moc udělat někoho jiného aktérem, nebo naopak divákem? Kdo nebo co určuje pravidla hry?“ (FISCHER-LICHTE 2011: 66).

Performanční umění je tak zjevně polem nejen pro dosažení štastné emancipované prézentnosti, ale také prostorem pro rozpoutání reálných mocenských bojů. Fischer-Lichte popisuje performance, „při [nichž] je obtížné jednoznačně rozlišit [...], kdo na koho vyvíjí nátlak, [kdy] každý účastník si nárokoval pozici subjektu a ostatní odsouval do pozice objektu“ (FISCHER-LICHTE 2011: 57), kdy byli účastníci nuceni režisérem či performery jednat a ovlivňovat dění performance navzdory své touze účastnit se těchto fází představení bez zásadních rozhodnutí (paradoxně ,jejich nevole z nich dělala přesně to, čím odmítali být," FISCHER-LICHTE 2011: 58), apod.

Specifický etický problém lze sledovat na dalším př́íladu, ve kterém Fischer-Lichte zdůrazňuje př́nos performančního umění. Pozitivní hodnotu shledává v tom, že performanční umění umožňuje díky prézentnosti zažít štěstí, které běžně lidé nezažívají: „Ve chvíli, kdy prézentnost představitele umožní divákům cítit sebe a prezentovat sebe sama jako vtělenou mysl, zaplaví je pocit štěstí, jaký se jim v běžném životě zažít nepodaří. [...] Pro jeho opětovné vyvolání je nutné opakované zakoušení prézentnosti. Diváci se na těchto vzácných okamžicích štěstí, které jim může poskytnout výhradně představitelova prézentnost, mohou stát závislými“ (FISCHER-LICHTE 2011: 144). Toto tvrzení je poměrně sporné, obzvlášt ve spojení s ihned následující větou, kde Fischer-Lichte píše: „Prézentností se nevyjevuje nic mimořádného, ale naopak něco zcela běžného, a to se stává událostí - tedy lidská predispozice být vtělenou myslí“ (FISCHER-LICHTE 2011: 144). Štěstí, které není možné zažít v běžném životě, ale pouze ve vzácných okamžicích prézentního performančního umění, je zároveň něčím zcela běžným. Fischer-Lichte tedy odmítla na počátku pracovat $s$ běžnými performancemi pro jejich př́lišnou běžnost, nedostatečnou estetičnost, aby následně ukázala, že estetičnost těchto estetických performancí spočívá v tom, že jsou zcela běžné. Její výklad vede tedy k tomu, že štěstí je možné zažít pouze v rámci performančního umění, které sytí běžný život tím, že umožňuje prožít to, co běžnému životu odebralo - jeho běžnost a každodennost. Na tomto sycení se člověk může stát závislým - nikoli tedy emancipovaným a rovnocenným, ale závislým. Všední život je odvozen z umění, které mu dodává krásu běžnosti a štěstí v závislosti. Abychom mohli běžnost žít štastně, musíme ji vysunout z jejího každodenního odvíjení a jako běžnou a ničím zvláštní ji vystavit. Tímto vystavením se na oči účastníkům performance se běžnost ozvláštní a získá specifickou hodnotu (koncept).

Uvedenými př́klady Fischer-Lichte stvrzuje, že v rámci jí redefinované situace performančního umění nedochází tak úplně k naplnění šsěstí civilizačního procesu, ale $\mathrm{k}$ nově ustaveným a často těžko kontrolovaným mocenským bojům, k manipulaci v rám- 
ci hypnotizujícího prostoru, $\mathrm{k}$ tvorbě emočních závislostí a ke vzniku potenciálu pro zneuživání, které se může vtělit natolik intenzivně, že se stane součástí sebeobrazu účastníka dlouho po ukončení performance. Otázka je, co se v rámci performančního umění skutečně účastníkům otevírá, co je znemožněno a jak performanční umění účastníky mění. $\mathrm{Z}$ uvedených př́íkladů se zdá nicméně vyplývat, že v rámci performančního umění nedochází $\mathrm{k}$ nějaké exemplární formě emancipace vůči hierarchickým dualitám, vztahům moci, $\mathrm{k}$ rovnosti vztahů a $\mathrm{k}$ záruce zážitku pravější běžnosti, než je ta, kterou běžně žijeme.

\section{Změna stanoviska}

V závěru knihy si Fischer-Lichte možná stále jasněji uvědomuje, že její výklad nevede k jednoznačnému prosazení estetiky singulární performance na úkor opakované inscenace. I když v průběhu svého výkladu mluví o nutnosti „striktně rozlišovat ,inscenaci“ a ,představení“ “ (FISCHER-LICHTE 2011: 70), kde inscenace sleduje plán, koncepci a ideu mocenské reprezentace, kdežto „představení je originální, jedinečné a neopakovatelné“ (FISCHER-LICHTE, 2011: 70), dospívá v závěru knihy k tvrzení, že „pro takové pojetí není v estetice performativity místo - v ní jsou estetika události s estetikou inscenace úzce a neoddělitelně spjaty" (FISCHER-LICHTE, 2011: 273). Souhlasí s tím, že „chápání ,prézentnosti“ a ,reprezentace“ jako dichotomie je neudržitelné“ (FISCHER-LICHTE 2011: 212), a začíná zdůrazňovat význam stavu mezi dvěma řády, zkušenostního prahu mezi prézentností a reprezentací, o který ve finále má jít. Tento stav „mezi a uprostřed,“ nabízí zkušenost liminální existence, percepční nestability a potenciálně i transformace. Fischer-Lichte popisuje liminální zkušenost jako stav, pro který se recipient nerozhodl a v němž u něj probíhají změny vnímání mezi reprezentací a prézentností. Tyto změny se rovněž dějí bez jeho zásluh: „V takovém momentu zakouší své vnímání jako emerzní, nezávislé na vlastní vůli či kontrole - jako neovlivnitelné, ale uvědomělé“ (FISCHER-LICHTE 2011: 214). Snaží se tak tvrdit, že liminální stav přemostuje reprezentaci a prézentnost skrze oscilaci mezi řády inscenace a performance. Vzápětí však zdůrazní, že řád reprezentace nastoluje vnímání, které zahrnuje „myšlenky jako představy a pocity, které se projevují vnitřními pochody a zř́dka bývají natolik silné, aby recipienta pohltily a znemožnily mu udržet odstup od toho, co vnímá“, kdežto řád prézentnosti má účinky „fyziologické, afektivní, energetické a motorické“, které vznikají „nepředvídatelně a v tomto smyslu ,chaoticky““, a jako takový je zárukou bezprostředního vzniku nekontrolovatelných „emerzí významů“. Liminální zkušenost tedy vzniká v performanci, nikoli mezi performancí a inscenací. Inscenace pouze zachovává performanci možnost neustrnout ve stabilizovaném řádu, vystupovat ze sebe.

V další kapitole Fischer-Lichte dokládá tuto významnost performance na př́ikladu performance Mariny Abramovićové. Ta ve svém představení Tomášovy rty uvádí diváky do liminální situace tím, že ruší kompletně řád reprezentace a vpravuje recipienty do estetické zkušenosti přihlížení trýznění. Estetická zkušenost tu má podobu krize, která 
je nakonec přinutí zasáhnout, a tudíž jednat. „Estetický prožitek tu byl zakoušen jako krize, jež není možné překonat pouhou rozumovou úvahou či kontemplací. [...] Estetické tu už neznamenalo nechat jednat, ale jednat.“ (FISCHER-LICHTE 2011: 228) Plyne z toho, že je to opět prézentnost sama, která je významotvorná, a to proto, že se v ní ztrácí ,jakoby“, odstup subjektu od předmětu jeho prožívání, rozumová úvaha tu ztrácí validitu. Otázkou je, jestli diváky nakonec nezvedla ze židlí právě rozumová úvaha, právě schopnost odstupu, která převládla nad všemi dalšími vjemy plynoucími z přihlížení sebetrýznění. Nezdá se, že by je vystavení této liminální zkušeností přivedlo do jiného stavu, nového zhodnocení reality, jiného sociálního postoje, ale rozhodli se ukončit danou situaci ve jménu hodnot, které již jim byly vlastní. Etika tak nesplynula s estetikou, ale přehlušila ji.

Tento př́íklad obhajoby liminality formou vyburcování publika pomocí vystavování eticky těžko únosného jednání je zároveň v rozporu s již zmíněným tvrzením, že performance je zpřítomněním, upozorněním na něco zcela běžného, všedního, čeho si v běžném životě už ani nevšímáme. Sebetrýznění není (snad) běžnou zkušeností našich životů a právě proto má sílu vyvolat etickou reakci. Liminalita, o které Fischer-Lichte mluví s odkazem na rituální teorie Arnolda van Gennepa, Richarda Schechnera a Viktora Turnera, je zde pojímána opět v jistém smyslu odvozeně, nebot liminalitu rituální pouze připomíná určitými rysy. Performance na rozdíl od přechodového rituálu nemění sociální status zúčastněných, jejich identitu, ani společenskou moc. A to je na ní právě zajímavé - herní vystoupení z kontextu života, které performance nabízí, není rituální změnou, není přechodem jinam, je setrváním ve stejném, které můžeme významově posunout.

Opět je příznačné, že poststrukturalistické pojetí, které nabízí tuto herní spjatost performativní re-prezentace a subverzivní události, Fischer-Lichte odmítá skrze vrcholně stereotypní kritiku. Postmoderna podle ní vychází z myšlenky „kompletní decentralizace“ subjektu a zbavuje ho jakékoli možnosti jednat: "Je-li subjekt kompletně decentralizován, je nemyslitelné, aby mohl cokoli spoluurčovat. Stává se objektem ovládaným entitami [...]. Tělo má být chápáno jako pasivní [...]. Všechno je arbitrární a každá zkušenost představuje subjektivní konstrukt“ (FISCHER-LICHTE 2011: 243).

Idea liminální zkušenosti však odporuje nejen výkladovým strategiím poststrukturalismu, ale i fenomenologie tělesnosti a filosofie hry. Tyto př́ístupy nepracují s topologií chaotického tranformativního mezistavu mezi dvěma řády skrze koncept liminality, ale vytvářejí herní pole uvnitř pole reálného, a to i když mluví o zkušenosti ilinx (nekontrolované závrati) či alea (nekontrolovatelné náhody), o chiasmatu (proplétání tělesné zkušenosti s pojmem) i metalepsi (zpětném ustavování subtance z performativního jednání). $\mathrm{V}$ těchto př́ístupech se setkáváme se složitou topologií druhé strany listu či slepé skvrny (Merleau-Ponty), sekundarity či parazitnosti, které se jako sekundarita a parazitnost stávají primárními kategoriemi lidského života. V odkazu na ně se může performance ukázat jako sekundární a diky tomu primární způsob uskutečňování skutečnosti.

Fischer-Lichte nabízí pojmově a argumentačně nestabilní výklady. Stejně ambivalentní jako tvrzení o vztahu inscenace a performance, jsou její tvrzení o vztahu 
umění a života. Na jedné straně tvrdí: „Přestože umělci neustále usilují o překročení, setření a dokonce anulování hranic mezi uměním a životem, estetickým a společenským, politickým a etickým principem, mohou jejich vystoupení autonomii umění reflektovat, nemohou ji však zrušit, nebot ji garantuje instituce umění. Každé umělcovo obrazoborecké gesto, které směřuje k rozboření umělecké instituce, se v této instituci odehrává a tím potvrzuje její hranice. Na tom nic nezmění ani estetika performativity“ (FISCHER-LICHTE 2011: 291-292) a o tři stránky později jen lakonicky zdůrazní: „Estetika performativity se soustředí na umění překračující hranice" (FISCHER-LICHTE 2011: 295). Kromě pojmových dvojic inscenace-performance, umění-život by stálo za to podrobné analýze podrobit i další její pojmy, jako je zpětnovazební smyčka (její otevřenost vnějšku a zároveň soběstačnost, její pozitivita a negativita) či liveliness. ${ }^{1}$

Shrňme nicméně, že koncept liminality, jak jej předkládá Fischer-Lichte, ideu dvou světů neruší, nýbrž pouze slabě a ex post zastírá. Fischer-Lichte má ve svém výkladu zjevně tendence korigovat svá původní tvrzení a v zásadě se performativním psaním dostává ke svému vlastnímu opravování, ovšem tato oprava není dostatečně hluboká. Zachovává dualismus dvou světů, který chtěla popřít, a zároveň tvrdí, že je popřít nejde.

\section{Řešení jedna a dvě, ale ne tři}

Zdá se tedy, že se Fischer-Lichte ve svém výkladu performance míjí se svým vlastním záměrem. Tím, že se zároveň odvolává na poststrukturalismus, hru, fenomenologii a východiska avantgardy, nemůže dospět než $\mathrm{k}$ neřešitelným protimluvům, které rozhodně nepatří do kategorie tvořivých paradoxů, ale do kategorie nepřesvědčivých pojmových i argumentačních oscilací. Fischer-Lichte se věcně, de facto, přiklání k patosu avantgardy jakožto jediného zdroje performativního obratu v rámci umělecké tvorby a snaží se její východiska de iure naroubovat na strukturalismus a teorii o žitém těle (Leib). Argumentačně postupuje tak, že na Austinovo problematické dělení performativů reaguje za pomoci prvního a druhého řešení a snaží se tvrdit, že je to v souladu s řešením číslo tři, které je však protichůdné.

Svým emancipačním krokem směrem k estetické performanci, jež není běžnou každodenní performancí, chtěla možná Fischer-Lichte zachránit specificitu umění a divadelního performativu. Paradoxní na tom je, že díky tomuto kroku nakonec principiální roli divadelního performativu pro skutečnost ztrácí. Aby přeci jen dosáhla svého záměru a ozřejmila výjimečnost umění, musí v důsledku poměrně násilně prohlašovat skutečnost umělecké performance za pravější zdroj štěstí civilizačního procesu, než jaký lze nalézt v každodennosti. Tím svou separaci dokončuje, aby ji v poslední části zdánlivě překlenula mostem liminality a rétorikou meziprostoru.

1 Za toto koncepční rozšíření děkuji anonymnímu recenzentovi této studie. 


\section{Dovětek}

V celém článku jsem se věnovala pouze Estetice performativity a filosofickým aspektům argumentů, které Erika Fischer-Lichte využívá v této knize. Jistě by šlo namítnout, že myšlení Fischer-Lichte nelze hodnotit z jedné knihy. O hodnocení samotné autorky jsem se ale ve svém článku nesnažila. Šlo mi především o systematickou reflexi důsledků určitých filosofických rozhodnutí, které se týkají volby pojmových distinkcí nebo strategií v kontextu performance a performativity. Dílo Eriky Fischer-Lichte je rozsáhlé a bezesporu nabízí další bohatý materiál k reflexi a přístup k divadelní tvorbě a performanci. Na druhé straně i v posledním významném díle autorky, v knize The Routledge Introduction to Theatre and Performance Studies (FISCHER-LICHTE 2016) najdeme obdobná rozlišení, která byla předmětem mé kritiky. Tím nejdůležitějším je její rozlišení na estetické a neestetické performance (FISCHER-LICHTE 2016: 41-44, 164) či zdůraznění singularity emergence významu oproti jeho sociální performativitě (FISCHER-LICHTE 2016: 39).

\section{Literatura}

AUSLANDER, Philip. 2006. From Acting to Performance. London/New York: Routledge, 2006. AUSTIN, John Langshaw. 2000. Jak udělat něco slovy. Praha: Filosofia, 2000.

BUTLER, Judith. 1990. Performative Acts and Gender Constitution: An Essay in Phenomenology and Feminist Theory. In Sue-Ellen Case (ed.). Performing Feminism: Feminist Critical Theory and Theatre. Baltimore/London: Johns Hopkins University Press, 1990: 270-282.

BUTLER, Judith. 1997. Excitable Speech: A Politics of the Performative. New York: Routledge, 1997.

BUTLER, Judith. 2017. When Gesture Becomes Event. Anna Street, Julien Alliot and Magnolia Pauker (edd.). Inter Views in Performance Philosophy. Crossings and Conversations. Basingstoke: Palgrave Macmillan, 2017: 171-191.

CARLSON, Marvin. 2018. Performance. A Critical Introduction. London: Routledge, 2018.

DERRIDA, Jacques. 1993. Texty k dekonstrukci. Práce z let 1967-72. Bratislava: Archa, 1993.

ERICKSON, Jon. 1995. The Fate of the Object: From Modern Object to Postmodern Sign in Performance, Art and Poetry. Ann Arbor (MI): University of Michigan Press, 1995.

FISCHER-LICHTE, Erika. 2011. Estetika performativity. Přeložila Markéta Polochová. Mníšek pod Brdy: Na konári, 2011.

FINK Eugen. 1992. Oáza štěstí. Praha: Mladá Fronta, 1992.

FRIED, Michael. 1968. Art and Objecthood. In Gregory Battcock (ed.). Minimal Art: A Critical Anthology. New York: Dutton, 1968: 116-147.

GREENBERG, Clement. 1961. Art and Culture: Critical Essays. Boston: Beacon Press, 1961.

HERRMANN, Max. 1981. Über die Aufgaben eines theaterwissenschaftlichen Instituts. In Helmar Klier (ed.). Theaterwissenschaft im deutschsprachigen Raum. Darmstadt: Wissenschaftliche Buchgesellschaft, 1981.

HUIZINGA, Johan. 1971. Homo ludens. Praha: Mladá Fronta, 1971.

KOUBOVÁ, Alice. 2019. Myslet z druhého mista. K otázce performativni filosofie. Praha: NAMU, 2019. LAGAAY, Alice. 2001. Metaphysics of Performance. Berlin: Logos Verlag, 2001. 


\section{doc. RNDr. Mgr. Alice Koubová, PhD., PhD.}

Oddělení současné kontinentální filosofie,

Filosofický ústav AV ČR,

Jilská 1, 11000 Praha 1, Česká republika

koubova@flu.cas.cz

Alice Koubová je vědeckou pracovnicí Filosofického ústavu AVČR, dlouhodobě přednáší na AMU Praha a hostuje na dalších divadelních školách v Čechách a ve světě. Ve svém výzkumu se zaměřuje na performativní a aplikovanou filosofii, kterou rozvijí ve spolupráci s českými veřejnými, především kulturními, institucemi (Národní Divadlo, Bazaar festival, TANTE HORSE, Studio ALTA, Alfréd ve Dvoře, Divadelní ústav, SNG Bratislava). Mezi její nejvýznamnější publikace patři Donald Winnicot a politická teorie (s Petrem Urbanem, Filosofia, 2020), Myslet z druhého místa. Kotázce performativní filosofie (NAMU, 2019), Artistic Research: Is There Some Method? (editorka s Danielou Jobertovou, NAMU, 2017) a Self-ldentity and Powerlessness (Brill, 2013).

Alice Koubová is an academic employee of the Institute of Philosophy of the Czech Academy of Sciences, and has been a lecturer at the Academy of Performing Arts in Prague as well as a guest lecturer in other theatre schools around Czechia, and the world. In her research, she focuses on applied philosophy and the philosophy of performance both of which she develops in cooperation with Czech state, mainly cultural, institutions (National Theatre, Bazaar festival, TANTE HORSE, Studio ALTA, Alfréd ve Dvoře, Divadelní ústav, SNG Bratislava). Among her most noted publications are Donald Winnicot a politická teorie (Donald Winnicot and A Political Theory) with Petr Urban (Filosofia, 2020), Myslet z druhého místa. Kotázce performativni filosofie (Ideas from a Second Perspective. On the Philosophy of Performance) (NAMU, 2019), Artistic Research: Is There Some Method? co-edited with Daniela Jobertová (NAMU, 2017), and Self-ldentity and Powerlessness (Brill, 2013). 